\title{
New Red-Flowered Crape Myrtles ${ }^{1}$
}

Gary W. Knox ${ }^{2}$

Selections of crape myrtle (Lagerstroemia spp.) ${ }^{3}$ with true red flowers are now widely available thanks to new and dramatic improvements in crape myrtle flower color. As with other colors of crape myrtle, red-flowered selections are free-flowering and will continue to produce flowers throughout summer and on into autumn. Moreover, red-flowered crape myrtles are available in all sizes, suitable for any sunny spot in the yard or in containers.

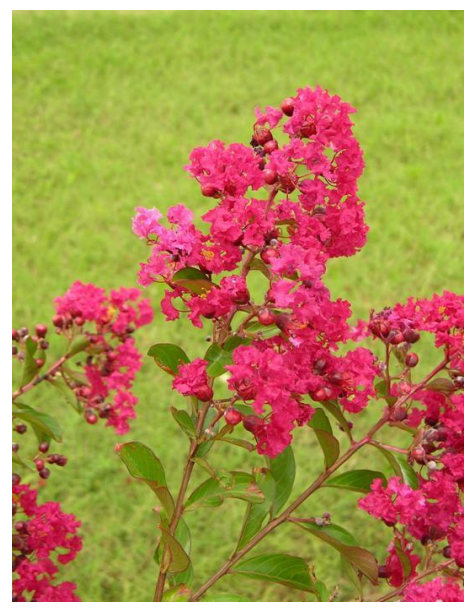

Figure 1. Petite Red Imp

\section{The Story of Red Crape Myrtles}

Wild crape myrtles from southeast Asia have flower colors ranging from white to pale lavender to watermelon-pink. Gardeners have long sought crape myrtles with clearer and more intense flower colors, but true red flowers have always been elusive. Finally in 1997, after years of intense breeding, Dr. Carl Whitcomb introduced Dynamite ${ }^{\circledR}$, the first crape myrtle with true red flowers.

Dynamite ${ }^{\circledR}$ was widely acclaimed for its red flowers and became hugely popular, inspiring searches for more red-flowered crape myrtles. Dr. Whitcomb continued his breeding and later introduced Red Rocket ${ }^{\circledR}$, Tightwad Red ${ }^{\circledR}$ and Siren $\operatorname{Red}^{\circledR}$, each maturing at a different size than Dynamite $^{\circledR}$. The U.S. National Arboretum also has an important Lagerstroemia breeding program and recently released red-flowered Arapaho and Cheyenne. A few older selections have long been recognized for their good red flower color, but they never achieved the acclaim and notoriety of these later, improved selections. Thanks to the popularity of Dynamite ${ }^{\circledR}$, red crape myrtles --- new and old --are now very popular and widely available.

\section{All Sizes and Shapes}

Not only do we now have crape myrtles with true red flowers, but they are available in different sizes suitable for various garden uses. Single- or multi-stemmed tree-form crape myrtles are ideal as

1. This document is ENH1019, one of a series of the Environmental Horticulture Department, Florida Cooperative Extension Service, Institute of Food and Agricultural Sciences, University of Florida. Original publication date May, 2006. Visit the EDIS Web Site at http://edis.ifas.ufl.edu.

2. Gary W. Knox, Professor, Cooperative Extension Service, Institute of Food and Agricultural Sciences, University of Florida, Gainesville, 32611.

The Institute of Food and Agricultural Sciences (IFAS) is an Equal Opportunity Institution authorized to provide research, educational information and other services only to individuals and institutions that function with non-discrimination with respect to race, creed, color, religion, age, disability, sex, sexual orientation, marital status, national origin, political opinions or affiliations. U.S. Department of Agriculture, Cooperative Extension Service, University of Florida, IFAS, Florida A. \& M. University Cooperative Extension Program, and Boards of County Commissioners Cooperating. Larry Arrington, Dean 




Figure 2. Tightwad Red

flowering specimen trees or as small, flowering trees near patios, walkways and entrances. Shrub forms make excellent accents in a shrub border when planted in groups. Dwarf plants are effective as large groundcovers, perennial bedding plants or container plants. Tree-size crape myrtles grow more than 12 feet tall in 10 years. Semi-dwarf crape myrtles grow between 4 and 12 feet tall in 10 years, and dwarf crape myrtles generally stay shorter than 4 feet, at least during the first 5 years.

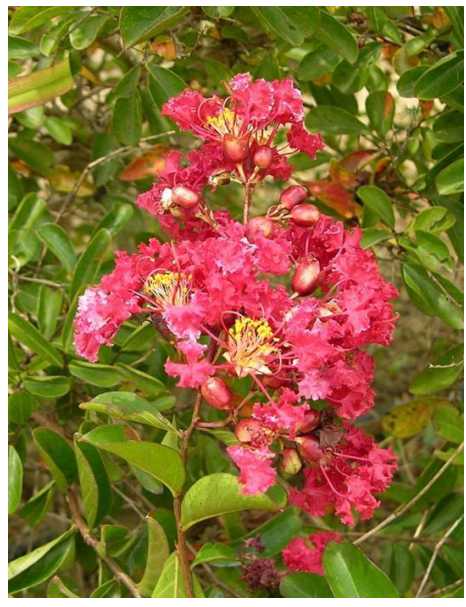

Figure 3. Victor

\section{Planting and Garden Care}

All crape myrtles need full sun. This is especially true with red-flowered crape myrtles since shade or cloudy weather can cause some selections to lose their red flower color. As with other crape myrtles, they are drought tolerant once established, but extra water encourages faster and larger growth. The same situation applies with fertilizer: crape myrtles don't require it but will grow faster if fertilizer is applied.



Figure 4. Cheyenne

Crape myrtles are tolerant of planting conditions with two exceptions. First, crape myrtles grow poorly in wet soils. Second, crape myrtles should not be planted too deep. Crape myrtle root systems grow best in well-aerated soil or near the soil surface, and plant growth, flowering and vigor are reduced when root systems are planted below the soil level or in wet, poorly drained soils.

Crape myrtles generally require little pruning if properly placed in the garden. Occasional pruning to improve plant shape may be done anytime after leaves have fallen. However, avoid hard pruning that removes stems or branches 3 or more inches in diameter. This severe pruning results in excess leafy growth, sprouting and delayed flowering. Tip pruning to remove old flower clusters promotes reflowering but is not practical for large plants or low maintenance gardens. Tip pruning is largely unnecessary on many newer red-flowered selections since they naturally repeat-bloom.

For best results and low maintenance, choose a selection whose ultimate size fits its place in the garden. With the new selections now available, a red-flowered crape myrtle is available in any size.

\section{Future Selections}

Breeders are continuing to improve and introduce new crape myrtles. The U.S. National Arboretum has a long-term crape myrtle breeding program with emphases on insect and disease resistance. University of Georgia professor Michael Dirr is introducing new dwarf crape myrtles, 


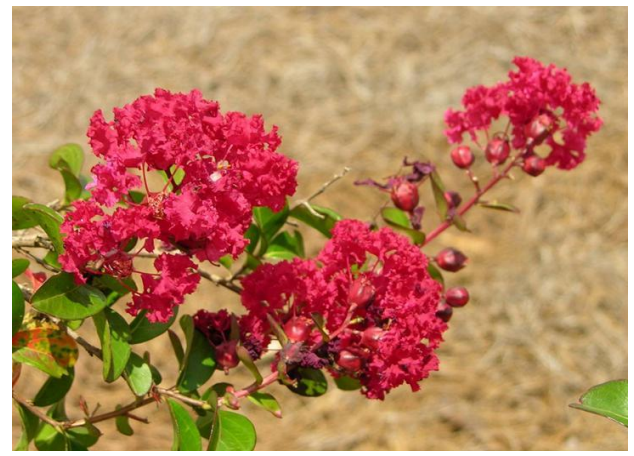

Figure 5. Christiana



Figure 6. Siren Red

including a new red-flowered selection called Cherry Dazzle. These and other breeders hope to broaden the ornamental appeal of crape myrtles even further by searching for new flower colors as well as red leaves that hold their color all summer long.

In the meantime, look for the red-flowered crape myrtles shown in figures $1-11$ and listed in the following section. I consider these to be the best of the red crape myrtles currently available.

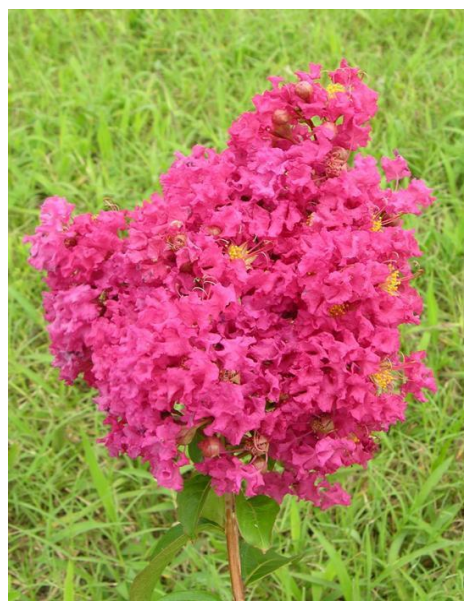

Figure 7. Tonto

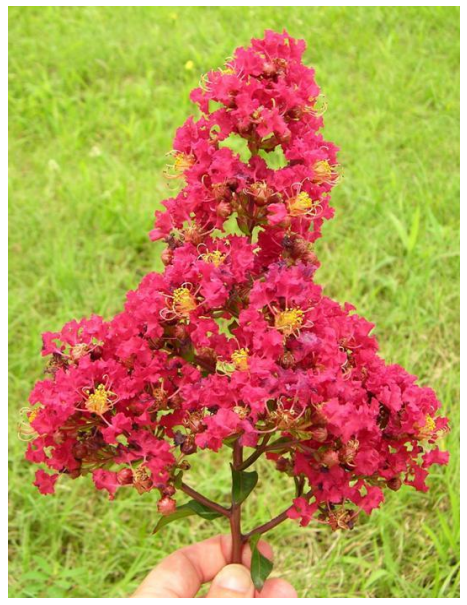

Figure 8. Arapaho

\section{Characteristics of Red-Flowered Crape Myrtles by Size and Common Name}

\section{Dwarf Red-Flowered Crape Myrtles (up to 4 feet tall)}

Petite Red Imp ${ }^{\mathrm{TM}}$ - Good red flowers on a plant with a rounded form. Trademarked name of Monimp.

Tightwad $\operatorname{Red}^{\circledR}-$ True red flowers on a rounded plant with dense foliage. Trademarked name of Whit V.

Victor - Great red flower color on a dwarf plant with a narrow form.

\section{Semi-Dwarf Red-Flowered Crape Myrtles (from 4 to 12 feet tall)}

Cheyenne- Bright red flowers on this new cultivar from the U.S. National Arboretum. Since it is a hybrid, it should be disease-resistant.

Christiana - Deep red flowers on an upright-rounded plant. Flowers earlier than most other selections.

Siren $\operatorname{Red}^{\circledR}$ - Dark red flowers on this new selection. Trademarked name of Whit VII.

Tonto - Fuchsia red flowers on this disease-resistant hybrid with a rounded form.

Tree-Size Red-Flowered Crape Myrtles (over 12 feet tall) 
Arapaho - Good red flowers on this new hybrid from the U.S. National Arboretum. Should be the best disease-resistant red crape myrtle.

Centennial Spirit - Dark red flowers on a stiffly upright plant.

Dynamite ${ }^{\circledR}-$ True red flowers on a stiff, upright-rounded plant. Cloudy weather can fade some flowers to the point they turn white. Trademarked name of Whit II.

Red Rocket ${ }^{\circledR}$ - Large clusters of cherry-red flowers on an upright-rounded plant. As with Dynamite $^{\circledR}$, cloudy weather fades red color and causes flecks of white on flowers. Trademarked name of Whit IV.

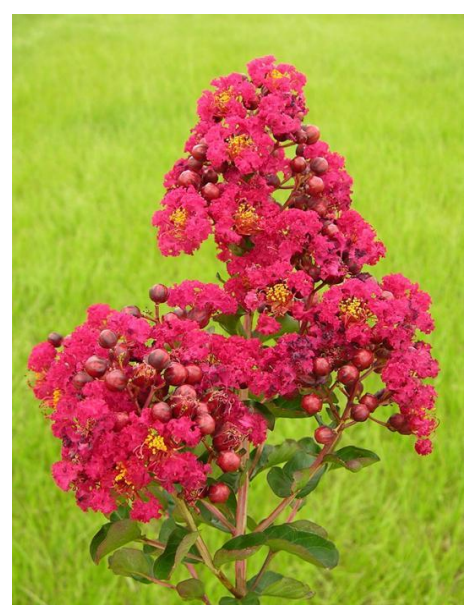

Figure 9. Centennial Spirit

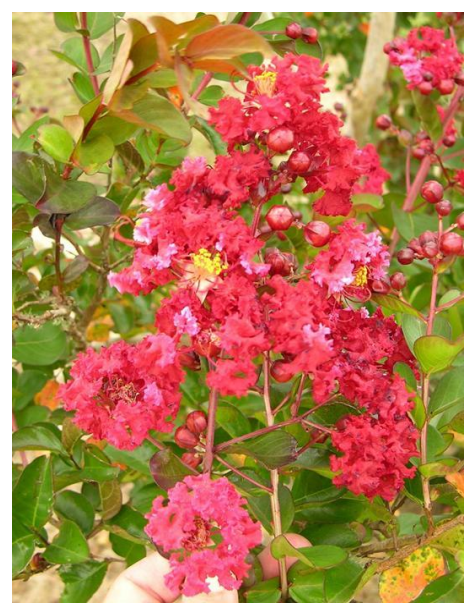

Figure 10. Dynamite



Figure 11. Red Rocket

\section{Reference}

Fox, A.M., D.R. Gordon, J.A. Dusky, L. Tyson, and R.K. Stocker (2005) UF/IFAS. Assessment of the Status of Non-Native Plants in Florida's Natural Areas. Cited from the Internet 18 May 2006, http://plants.ifas.ufl.edu/assessment.html

\section{Additional Notes:}

3. Lagerstroemia indica has been evaluated using the IFAS Assessment of the Status of Non-Native Plants in Florida's Natural Areas (Fox et al. 2005). It is not considered a problem species and may be recommended for use in Florida. Lagerstroemia fauriei and L. indica $x$ fauriei have not yet been evaluated, and may be recommended for use. 